\title{
Histological and Morphological Aspects of Reproduction in Male Blackspotted Smooth-Hound Mustelus punctulatus in the Adriatic Sea (Eastern Mediterranean Sea)
}

\author{
Romana Gračan and Gordana Lacković \\ Division of Zoology, Department of Biology, Faculty of Science, University of Zagreb, 10000 Zagreb, Croatia \\ Correspondence should be addressed to Romana Gračan; romana.gracan@biol.pmf.hr
}

Received 29 April 2016; Accepted 12 July 2016

Academic Editor: Jakov Dulčić

Copyright (C) 2016 R. Gračan and G. Lacković. This is an open access article distributed under the Creative Commons Attribution License, which permits unrestricted use, distribution, and reproduction in any medium, provided the original work is properly cited.

\begin{abstract}
We present first data on reproductive biology of male blackspotted smooth-hound Mustelus punctulatus in the Adriatic Sea and first histological examination of gonads at different maturation stages and seasonal cycles for this species. We collected samples from 117 male specimens of $M$. punctulatus ranging in length from 44.6 to $126.5 \mathrm{~cm}$, caught by commercial bottom trawls in the NorthCentral Adriatic Sea. Microscopic observation revealed a diametric development of testes, in which round-shaped spermatocysts have zonal arrangement, showing seven different stages of development. Males began to mature when they were between 61 and $88 \mathrm{~cm}$ body length, which was indicated by the presence of functional claspers or appearance of the spermatogenic cysts. While the smallest mature shark was only $80 \mathrm{~cm}$ long, all animals longer than $89 \mathrm{~cm}$ were sexually mature. The seasonal analysis of the testes indicated that mature spermatozoa dominated in testes during the first half of the year with a peak in May and June, after which followed less active period during July and August.
\end{abstract}

\section{Introduction}

The Adriatic Sea is a shallow, highly productive but heavily exploited basin in the eastern Mediterranean Sea. Intensive fishing has already caused changes in the composition and distribution of fish assemblage in the Adriatic, including the decrease in the biomass of demersal elasmobranchs [13]. The action plan for the conservation of cartilaginous fishes in the Mediterranean [4] emphasizes the importance of developing management plans for commercially exploited sharks and collecting regional life history information for data deficient species. One of the most important areas in understanding life history patterns and managing shark resources is reproductive biology, which requires a precise knowledge of basic reproductive parameters like seasonal cycles and developmental stages of species.

The genus Mustelus (family Triakidae, order Carcharhiniformes) is a wide-ranging group of at least 20 species of demersal mesopredatory sharks found on the shelves and uppermost slopes of temperate and tropical continental seas. Mustelus punctulatus (Risso, 1826) is a commercially exploited species, distributed along the continental shelf in the Mediterranean Sea and off the coast of Western Sahara in the Atlantic Ocean [5]. Given its narrow distribution range, confusion with other Mustelus species, and a lack of data on its basic biology and catches, this species is currently assessed by IUCN as data deficient [5]. With the exception of macroscopic reproductive descriptions from the central Mediterranean Sea [6, 7], there is little biological information available to guide its management.

The male reproductive system in sharks involves testes, genital ducts, urogenital papilla, siphon sacs, and claspers. Many studies analyse claspers, paired tube-like copulatory organs which elongate and calcify through maturation to determine sexual maturity. On the other hand, to comprehensively analyse timing of reproductive cycle, microscopic examination of testes and their functional units called spermatocysts is performed. Spermatocysts of elasmobranchs are closed spherical units with germ cells and Sertoli cells, in which spermatogenesis occurs [8]. 


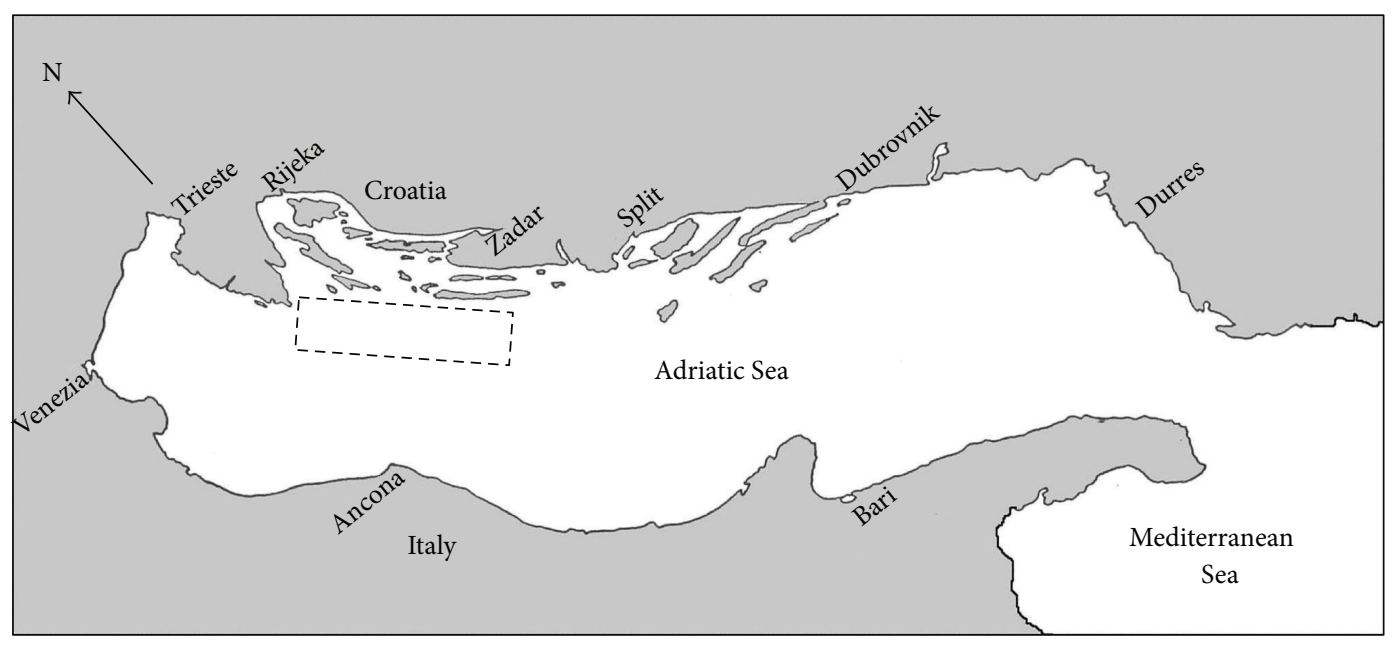

FIGURE 1: Study area in the Adriatic Sea is marked with a dotted rectangle. Arrow is pointing north (N).

Given the need for critical life history data, the lack of microscopic examination of $M$. punctulatus gonads, and complete lack of reproductive information from the Adriatic Sea, this study provides first histological description of testicular development and seasonal changes in blackspotted smooth-hounds in the North-Central Adriatic Sea.

\section{Material and Methods}

We collected samples from 117 male specimens of blackspotted smooth-hounds, caught by commercial bottom trawls in the North-Central (NC) Adriatic Sea (Figure 1), on depths between 45 and 84 m, from April 2005 to January 2007. Samples were collected from sharks selected by fishermen for sale, with additional samples obtained from several large catches of smaller animals that were to be discarded as bycatch. Specimens were identified $[9,10]$, sexed by visual inspection of pelvic fins, and measured for total body length (TL), clasper length (CL), and body weight (BW). We dissected sharks, excised testes from the epigonal organs, weighted testes (TW), fixed them in 10\% neutral formaldehyde for $48 \mathrm{~h}$, and later stored them in $70 \%$ ethanol.

We calculated gonadosomatic index $(\mathrm{GSI}=\mathrm{TW} / \mathrm{BW} *$ 100) for mature males and compared the GSI throughout the year to identify seasonal patterns of testes development. Seasonal differences in the GSI values were tested with ANOVA performed in SPSS 17.0 (SPSS Inc., USA). While the mating season can be estimated by assuming that mating occurs when the GSI reaches its highest value, this period may be also analysed through histological examination of the testes. Therefore, we collected tissue from the medial part of the testes and processed it for the routine paraffin sections. Samples were dehydrated through a graded ethanol series, exposed to chloroform, and embedded in Paraplast embedding media (Sherwood Medical, USA). Paraffin blocks were sectioned on a rotating microtome at $6-8 \mu \mathrm{m}$, and slides were stained with hematoxylin-eosin and viewed through a light microscope with a digital camera AxioCam ERc 5s
(Carl Zeiss Microscopy GmbH). Morphometric measures were performed on digital images using software Zen 2 (Carl Zeiss Microscopy $\mathrm{GmbH}$ ). We measured the proportion of the testis occupied by different spermatogenic stages along three parallel straight lines across the section of the testis $[11,12]$. The mean proportion of the testis occupied by each stage through different months of the year was analysed in mature males to determine if there was a recognizable seasonal pattern in testis development.

Maturity stages were divided into three general categories: immature, maturing, and mature. Sexual maturity of males was based on calcification of claspers, histological examination of testes, and classification of spermatocysts $[11,12]$. The presence of spermatocysts in the late stages of spermatogenesis (stages IV-VII) was considered as reproductive readiness of gonads [13-15].

\section{Results and Discussion}

In total, we analysed 117 males, ranging in length from 44.6 to $126.5 \mathrm{~cm}$ (mean TL: $76.1 \pm 20.4 \mathrm{~cm}$ ). Size distribution showed that sample was dominated by juveniles, ranging from 50 to $80 \mathrm{~cm} \mathrm{TL} \mathrm{(47.0 \% ),} \mathrm{and} \mathrm{smaller} \mathrm{adults} \mathrm{ranging} \mathrm{from} 90$ to $110 \mathrm{~cm}$ TL (28.2\%), while larger animals (110-130 cm TL) were quite rare $(N=3)$.

Immature males (TL range: $44.6-78.3 \mathrm{~cm} ; N=56$ ) had flexible and uncalcified claspers (CL range: $4.3-4.9 \mathrm{~cm}$ ) and small testes (TW range: $0.03-2.53 \mathrm{~g}$ ) enveloped in epigonal organ, which made it difficult to distinguish the testis from the epigonal organ. Maturing males (TL range: $61.2-88.2 \mathrm{~cm}$; $N=16$ ) had larger, flexible, and partially calcified claspers (CL range: $3.1-6.9 \mathrm{~cm}$ ) and larger testes (TW range: $0.25-$ $7.05 \mathrm{~g})$, still enveloped in the epigonal organ. Mature males (TL range: $80.0-126.5 \mathrm{~cm} ; N=45$ ) had fully developed claspers (CL range: $7.1-13.2 \mathrm{~cm}$ ) and large testes (TW range: 1.51-28.71 g) easily recognizable from the epigonal organ. Average bimonthly GSI of mature males revealed some differences, although significant statistical differences were not 


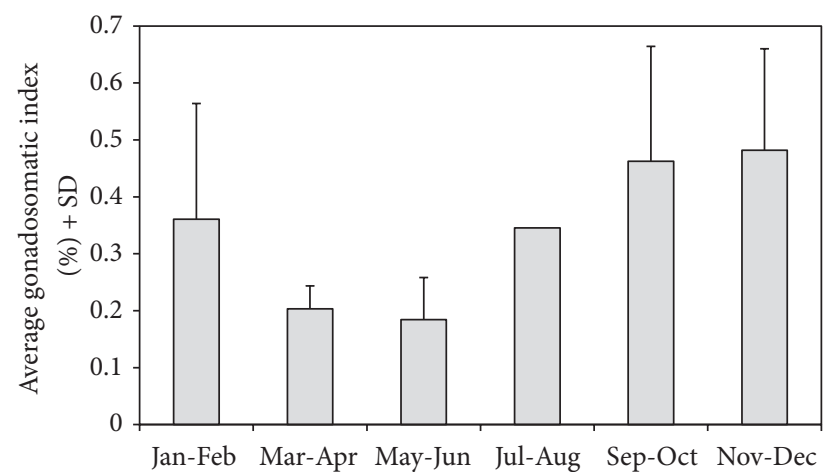

FIGURE 2: Temporal changes in the average gonadosomatic index (+ standard deviation (SD)) of mature male Mustelus punctulatus in the Adriatic Sea.

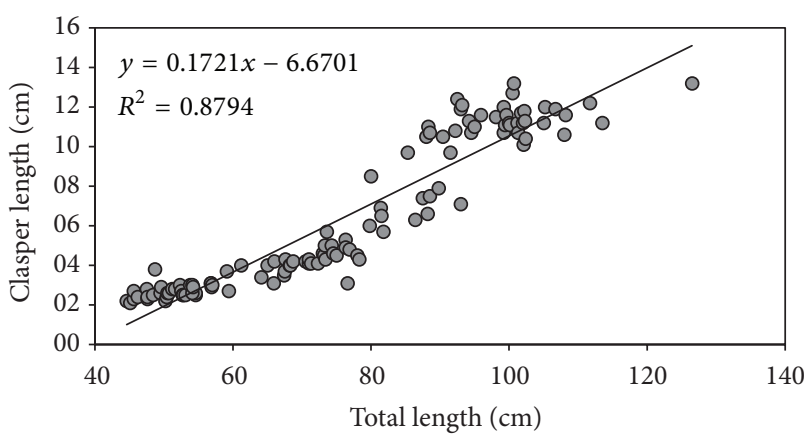

FIGURE 3: Relationship between the clasper length and the total body length of Mustelus punctulatus in the Adriatic Sea.

recorded (ANOVA $F=1.499, p=0.242$; Figure 2). Claspers increased in length with increase in body length (Pearson correlation $r=0.938, p<0.001)$. Clasper length grew faster as the shark approached maturity, but after reaching maturity they grew at a slower rate (Figure 3).

Microscopic observation of $M$. punctulatus testes revealed a diametric development, in which round-shaped spermatocysts have zonal arrangement. Diametric development, in which spermatogenesis extends from one wall across the diameter of the testis to the opposite wall with efferent ducts [16], was described for the shark families Carcharhinidae, Sphyrnidae, Somniosidae, Centrophoridae, Hemiscylliidae, and Triakidae [17-20]. The gross testis morphology, association of testis with the epigonal organ, and microscopic anatomy described in this study correspond with the previous studies on closely related sharks [17].

Spermatogenic cysts first appeared in maturing males around $67 \mathrm{~cm}$ TL. In mature males spermatocysts (cysts) contained seven distinct stages, as described for Mustelus canis [12], after [11]. Stage one consisted of spermatogonia and loosely organized germ cells. Stage two confined spermatogonia and Sertoli cells bounded by a basement membrane in spermatocysts. Stage III was visible as an enlarged cyst filled with large spermatocytes in the peripheral position. Stage four spermatocysts enclosed spermatids, while stage five consisted of cysts with immature sperm. Stage six was recognizable by spermatocysts with tightly shaped packets of spermatozoa, arranged spirally along the outside of the cysts, and in stage seven they were visible "degenerate" empty spermatocysts, with some free spermatogonia and free spermatozoa (Figure 4).

Maturing males in the present study ranged in TL from 61.2 to 88.2 , whilst all mature males were larger than $89 \mathrm{~cm}$ TL. The smallest sexually mature male had $80.0 \mathrm{~cm}$ TL and $8.5 \mathrm{~cm} \mathrm{CL}$, and testes contained spermatocysts in stages from one to five. Two studies on M. punctulatus from Tunisian waters reported that sharks mature at sizes from 76 to $88.5 \mathrm{~cm}$ TL [7] and when larger than $90 \mathrm{~cm}$ TL [6]. In comparison with the two aforementioned studies [6,7], our values fit well within the reported body sizes of animals.

Production and maintenance of mature spermatocysts within the testes was visible almost throughout the year. The seasonal analysis of the testes indicated that the proportion of mature spermatozoa is the highest between January and June. There is a sharp decline in the proportion of mature sperm during July and August with dominance of spermatogonia and spermatocytes, which indicates that testes are during this period less active (Figure 5). Hence, majority of spermatogenesis begins during September and October when testes become active and produce large number of spermatids, with evident decrease in number of spermatogonia and spermatocytes. Spermatogenesis continues through JanuaryApril when spermatids develop into immature and mature sperm. Movements of the GSI in adult males in this study suggested that testes were slightly larger between September and December, in comparison to period from March to June, when GSI index was lower. Thus, the increase in gonad size corresponds to the maturation of spermatogonia and spermatocytes into spermatocytes and spermatids. The similar periodical activity was recorded for Atlantic stingray (Dasyatis sabina), which showed that the maximum GSI was approximately 3-4 months prior to the peak of sperm production and that testes were the largest when spermatocytes started to develop [11]. Further on, in M. griseus, M. manazo, and Sphyrna tiburo, male GSI peaks 6 months before the defined mating season [21, 22]. Research conducted on $M$. punctulatus along the eastern coast of Tunisia [7] showed that majority of spermatogenesis occurs during autumn, whilst the mating season is in May and June. Similarly, the study on $M$. canis in the north Atlantic Ocean reported that mating likely occurs between May and September while mature spermatozoa occupy the largest area of the testis during May [12]. Therefore, it seems that spermatogenesis is continuous through autumn, winter, and spring months, with a mating period during spring (May and June). It should be mentioned that many species of male elasmobranchs are able to store sperm in their epididymis or seminal vesicles [23]. For instance, seminal vesicle size is the highest four months after maximum GSI which indicates that males store sperm produced before the season of mating [11].

Hence, although GSI is useful when displaying changes in testicular size, it may not always provide correct assessment of reproductive activity in elasmobranchs. Similarly, the use of visual macroscopic inspection of genital tracts for 


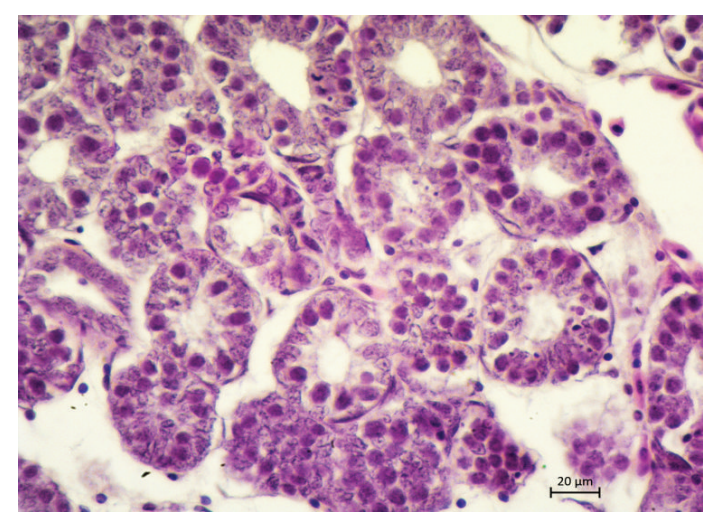

(a)

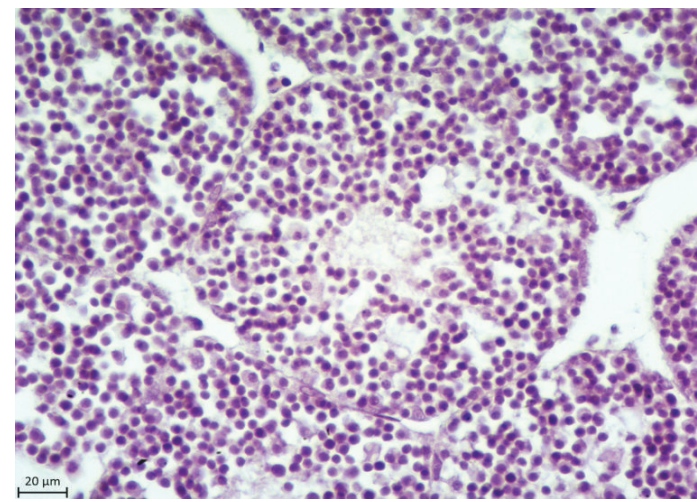

(c)

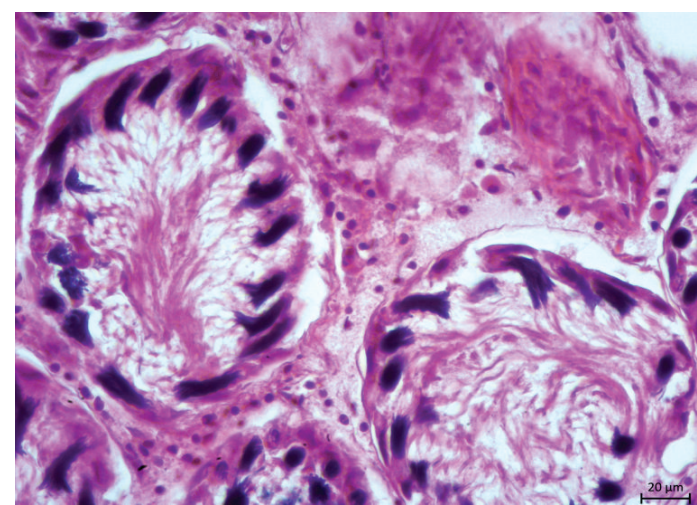

(e)

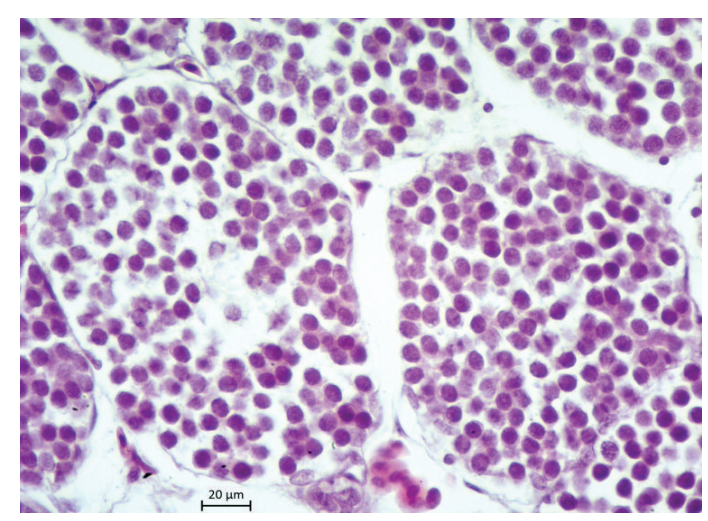

(b)

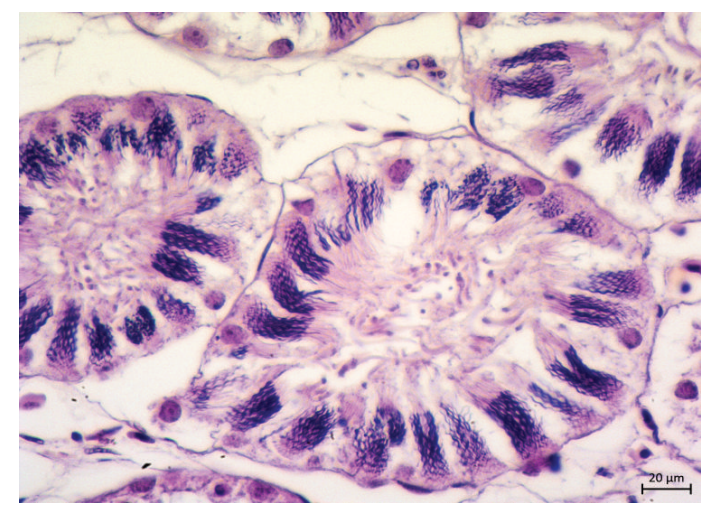

(d)

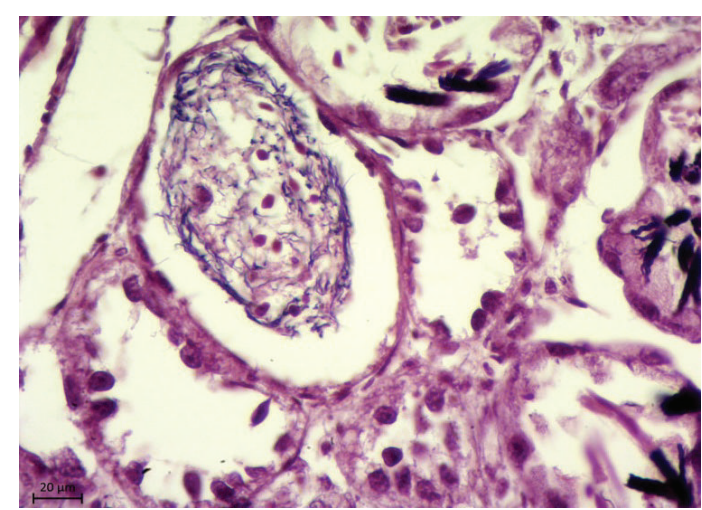

(f)

FIGURE 4: Spermatogenetic stages in testes of mature Mustelus punctulatus: (a) spermatogonia, (b) spermatocytes, (c) spermatids, (d) immature sperm, (e) mature sperm, and (f) empty spermatocysts. HE, bar $=20 \mu \mathrm{m}$.

determining the proportion of mature animals may lead to an overestimation of the size at sexual maturity. Thus, the practice of microscopic examination of gonads may be more consistent and reliable in maturity studies and for describing seasonal patterns $[24,25]$. This study shows the importance of applying both microscopic and macroscopic analyses, as these are necessary to estimate accurate biological characteristics. This is especially relevant for assessment and management of data deficient and commercially exploited sharks like M. punctulatus.
Although Mustelus spp. landings dominate in the north Adriatic with $>60 \%$ of elasmobranch catches [26], due to species $\mathrm{K}$ selected life history traits and lack of some basic biological data, management actions for M. punctulatus in the Adriatic Sea should be planned with caution. Since it is possible that even small increase in fishing may induce higher commercial mortality and have negative impact [27] on local population, further research and effective scientifically based management actions should be priority for this species. 


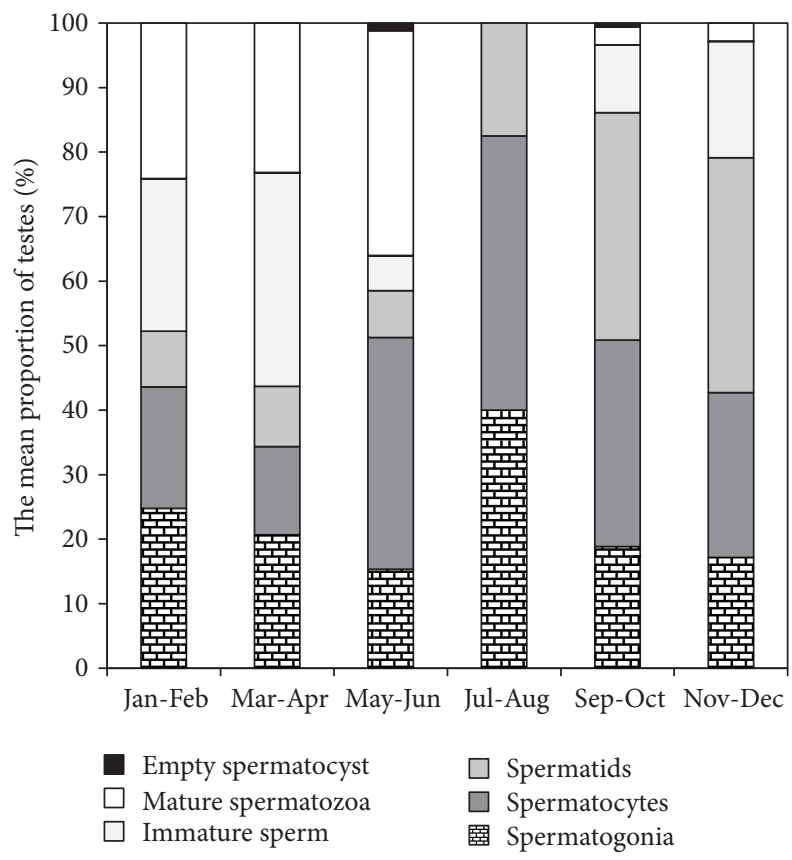

Figure 5: The mean proportion of the testes occupied by seven stages of spermatocyst development throughout different months of the year.

\section{Competing Interests}

The authors declare that there are no competing interests regarding the publication of this paper.

\section{Acknowledgments}

This study was carried out within Research Project no. 1191193080-3171 of the Ministry of Science, Education and Sport of the Republic of Croatia. The authors are thankful to B. Lazar (University of Primorska, Slovenia), all collaborating fishermen from Mali Lošinj (Croatia), and scientists from the Blue World Institute of Marine Research and Conservation in Veli Lošinj (Croatia) for their help with the sampling. They would like to thank Dr. P. Kružić (University of Zagreb, Croatia) for providing map of the Adriatic Sea.

\section{References}

[1] S. Jukic-Peladic, N. Vrgoc, S. Krstulovic-Sifner et al., "Longterm changes in demersal resources of the Adriatic Sea: comparison between trawl surveys carried out in 1948 and 1998," Fisheries Research, vol. 53, no. 1, pp. 95-104, 2001.

[2] N. Vrgoč, E. Arneri, S. Jukić-Peladić et al., "Review of current knowledge on shared demersal stocks of the Adriatic Sea," FAOMiPAF Scientific Cooperation to Support Responsible Fisheries in the Adriatic Sea GCP/RER/010/ITA/TD-12, AdriaMed Technical Documents, no. 12, 2004.

[3] M. Coll, A. Santojanni, I. Palomera, and E. Arneri, "Food-web changes in the Adriatic Sea over the last three decades," Marine Ecology Progress Series, vol. 381, pp. 17-37, 2009.
[4] UNEP MAP RAC/SPA, Action Plan for the Conservation of Cartilaginous Fishes (Chondrychthyans) in the Mediterranean Sea, RAC/SPA, Tunis, Tunisia, 2003.

[5] F. Serena, C. Mancusi, F. Haka, G. Morey, and T. Schembri, "Mustelus punctulatus," The IUCN Red List of Threatened Species, 2009.

[6] C. Capape and J. P. Quignard, "Contribution a la biologie des Triakidae des cotes tunisiennes," Bulletin de l'Office National des Pêches, vol. 1, no. 1, pp. 103-122, 1977.

[7] B. Saïdi, M. N. Bradaï, and A. Bouaïn, "Reproductive biology and diet of Mustelus punctulatus (Risso, 1826) (Chondrichthyes: Triakidae) from the Gulf of Gabès, central Mediterranean Sea," Scientia Marina, vol. 73, no. 2, pp. 249-258, 2009.

[8] W. S. Hoar and D. J. Randall, Fish Physiology, Academic Press, New York, NY, USA, 1969.

[9] I. Jardas, Adriatic ichthyofauna, Školska Knjiga, Zagreb, Croatia, 1996.

[10] L. Lipej, A. De Maddalena, and A. Soldo, Sharks of the Adriatic Sea, Knjižnica Annales Majora, Koper, Slovenia, 2004.

[11] K. P. Maruska, E. G. Cowie, and T. C. Tricas, "Periodic gonadal activity and protracted mating in elasmobranch fishes," The Journal of Experimental Zoology, vol. 276, no. 3, pp. 219-232, 1996.

[12] C. L. Conrath and J. A. Musick, "Reproductive biology of the smooth dogfish, Mustelus canis, in the northwest Atlantic Ocean," Environmental Biology of Fishes, vol. 64, no. 4, pp. 367$377,2002$.

[13] M. R. Heupel, J. M. Whittier, and M. B. Bennett, "Plasma steroid hormone profiles and reproductive biology of the epaulette shark, Hemiscyllium ocellatum," Journal of Experimental Zoology, vol. 284, no. 5, pp. 586-594, 1999.

[14] T. C. Tricas, K. P. Maruska, and L. E. L. Rasmussen, "Annual cycles of steroid hormone production, gonad development, and reproductive behavior in the Atlantic stingray," General and Comparative Endocrinology, vol. 118, no. 2, pp. 209-225, 2000.

[15] J. A. Sulikowski, J. Kneebone, S. Elzey et al., "The reproductive cycle of the thorny skate Amblyraja radiata in the western Gulf of Maine," Fishery Bulletin, vol. 103, no. 3, pp. 536-543, 2005.

[16] W. C. Hamlett, Sharks, Skates, and Rays: The Biology of Elasmobranch Fishes, The Johns Hopkins University Press, Baltimore, Md, USA, 1999.

[17] H. L. Pratt, "Elasmobranch gonad structure: a description and survey," Copeia, vol. 1988, no. 3, pp. 719-729, 1988.

[18] M. Girard, P. Rivalan, and G. Sinquin, "Testis and sperm morphology in two deep-water squaloid sharks, Centroscymnus coelolepis and Centrophorus squamosus," Journal of Fish Biology, vol. 57, no. 6, pp. 1575-1589, 2000.

[19] M. Kassab, T. Yanai, K. Ito, H. Sakai, T. Mesegi, and M. Yanagisawa, "Morphology and lectin histochemistry of the testes of brown-banded bamboo shark (Chiloscyllium punctatum)," Journal of Veterinary Anatomy, vol. 3, pp. 49-66, 2009.

[20] M. G. do Rêgo, J. L. Fitzpatrick, F. H. V. Hazin, M. L. G. Araujo, M. E. G. Barros, and J. E. Neto, "Comparison of the morphology and histomorphometry of spermatogenic cyst of three sharks species with diametric testes," The Anatomical Record, vol. 299, no. 6, pp. 759-768, 2016.

[21] K. Teshima, "Studies on the reproduction of the Japanese smooth dogfishes, Mustelus manazo and Mustelus griseus," Journal of Shimonoseki University of Fisheries, vol. 29, pp. 113199, 1981. 
[22] G. R. Parsons and H. J. Grier, "Seasonal changes in shark testicular structure and spermatogenesis," Journal of Experimental Zoology, vol. 261, no. 2, pp. 173-184, 1992.

[23] H. L. Pratt Jnr and S. Tanaka, "Sperm storage in male elasmobranchs: a description and survey," Journal of Morphology, vol. 219, no. 3, pp. 297-308, 1994.

[24] O. S. Kjesbu, J. R. Hunter, and P. R. Witthames, Report of the Working Group on Modern Methods to Assess Maturity and Fecundity in Warm-and Cold-Water Fish and Squids, John Grieg Grafisk AS, Norge, Norway, 2003.

[25] H. Murua, G. Kraus, F. Saborido-Rey, P. R. Witthames, A. Thorsen, and S. Junquera, "Procedures to estimate fecundity of marine fish species in relation to their reproductive strategy," Journal of Northwest Atlantic Fishery Science, vol. 33, pp. 33-54, 2003.

[26] A. Barausse, V. Correale, A. Curkovic et al., "The role of fisheries and the environment in driving the decline of elasmobranchs in the northern Adriatic Sea," ICES Journal of Marine Science, vol. 71, no. 7, pp. 1593-1603, 2014.

[27] N. K. Dulvy and R. E. Forrest, "Life histories, population dynamics, and extinction risks in Chondrichthyans," in Sharks and Their Relatives: Biodiversity, Adaptive Physiology and Conservation, J. C. Carrier, J. A. Musick, and M. R. Heithaus, Eds., pp. 639-679, CRC Press, London, UK, 2010. 

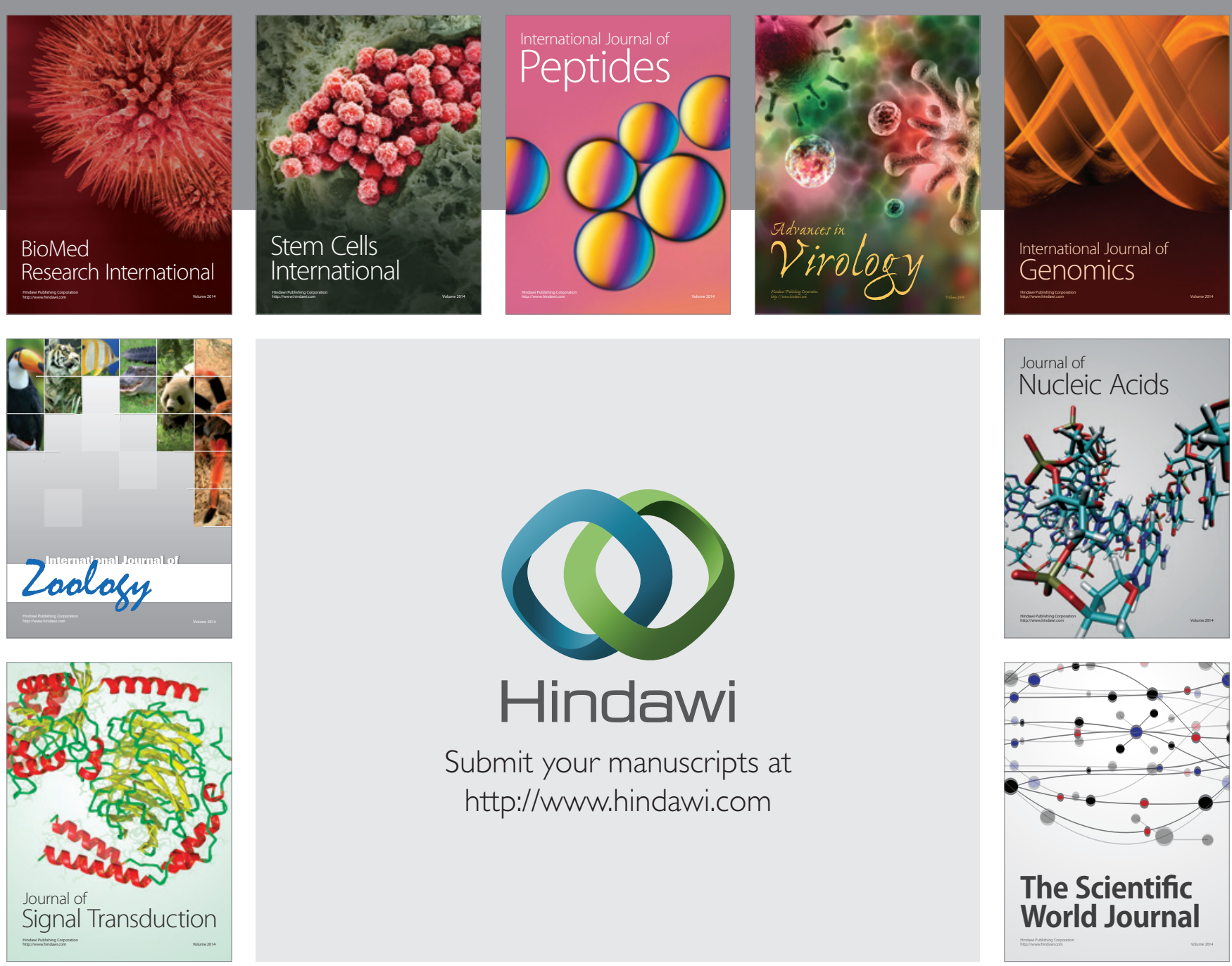

Submit your manuscripts at

http://www.hindawi.com
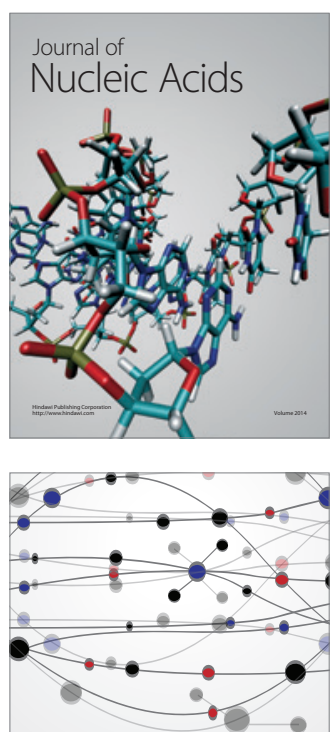

The Scientific World Journal
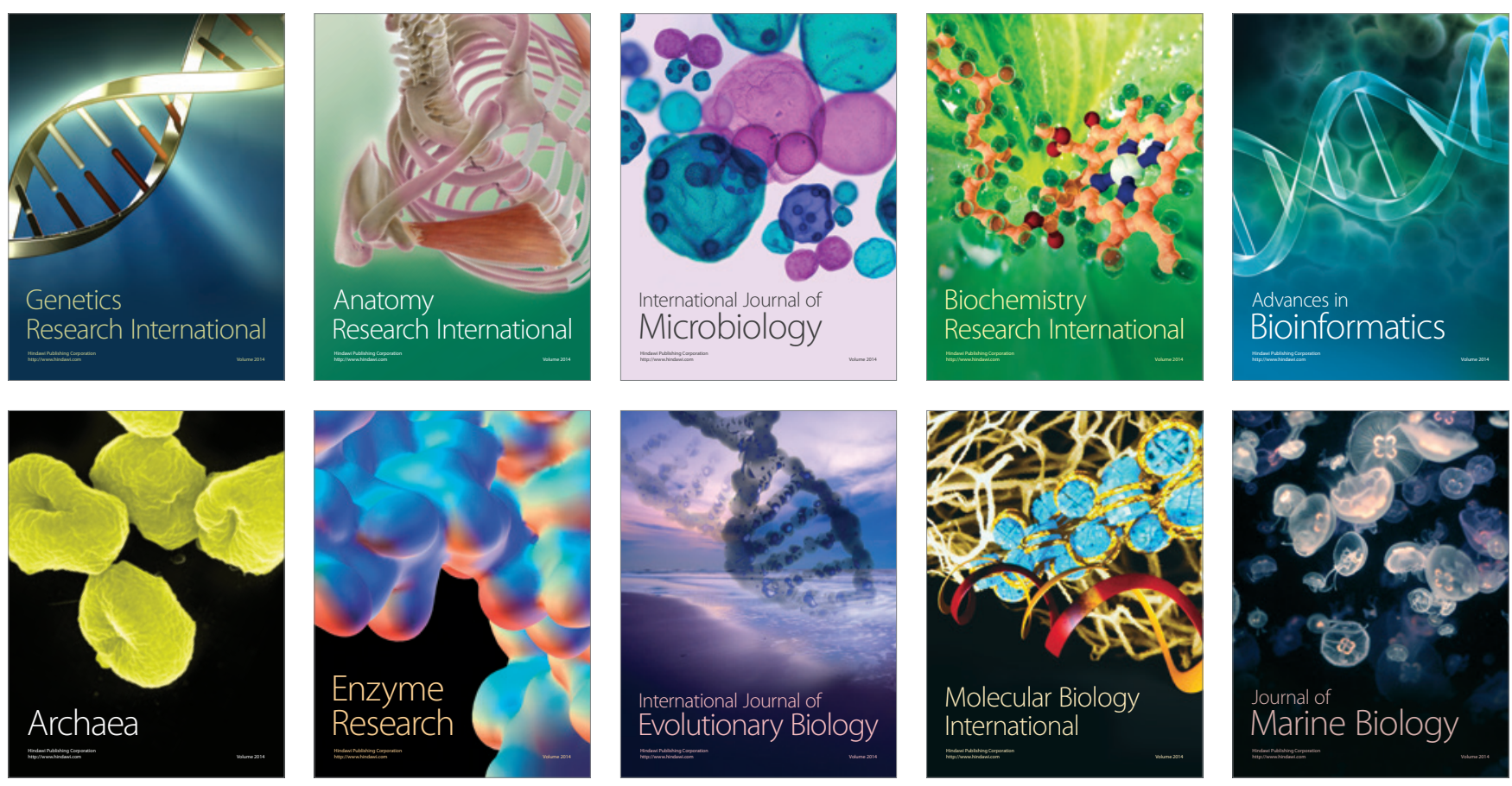